\title{
PENILAIAN PELAKSANAAN PROGRAM PENGEMBANGAN AGRIBISNIS PETERNAKAN SAPI POTONG DI KABUPATEN SEKADAU, KALIMANTAN BARAT
}

\section{ASSESSMENT OF AGRIBUSINESS DEVELOPMENT PROGRAM IMPLEMENTATION OF BEEF CATTLE FARMING IN SEKADAU REGENCY, WEST KALIMANTAN}

\author{
Mikael Heri Setiyo Wibowo ${ }^{1 *}$, Budi Guntoro ${ }^{2}$, dan Endang Sulastri ${ }^{2}$ \\ ${ }^{1}$ Dinas Peternakan, Kabupaten Sekadau, Kalimantan Barat \\ ${ }^{2}$ Fakultas Peternakan, Universitas Gadjah Mada, Jl. Fauna No. 3, Bulaksmumur, Yogyakarta, 55281
}

\section{INTISARI}

Tujuan penelitian ini adalah untuk mengkaji karakteristik sosial demografi peternak penerima bantuan program dan untuk menilai proses pelaksanaan program pengembangan agribisnis peternakan sapi potong di Kabupaten Sekadau. Penelitian dilaksanakan dari bulan Agustus sampai dengan Oktober 2009. Responden yang digunakan sebanyak 108 peternak penerima bantuan sapi potong di lima desa lokasi penyebaran ternak bantuan yang diperoleh dengan metode Proportionate Random Sampling. Data peningkatan populasi, jumlah penggaduh, karakteristik sosial demografi responden dan kontribusi penerimaan dari beternak sapi potong dianalisis secara deskriptif kuantitatif. Data proses pelaksanaan program, input, implementasi program dianalisis secara deskriptif kualitatif. Hasil penelitian menunjukkan peningkatan populasi sapi potong sebanyak 152 ekor dan jumlah penggaduh sebanyak 58 orang. Karakteristik peternak rerata umur 42,30 $\pm 5,87$ tahun, tingkat pendidikan paling banyak SD sebesar $43,52 \%$, rerata pengalaman beternak 1,61 $\pm 1,20$ tahun, rerata kepemilikan ternak 1,88 $\pm 1,05$ UT (Unit Ternak), jumlah tanggungan keluarga 3,36 $\pm 1,15$ orang, dan rerata alokasi waktu beternak sebesar 0,078 $\pm 0,082 \mathrm{HOK} / \mathrm{UT} / \mathrm{hari}$. Kontribusi penerimaan dari beternak sapi potong rerata sebesar $8,21-24,09 \%$ per tahun dari penerimaan keluarga. Kegiatan sosialisasi program di Kabupaten Sekadau belum efektif karena peternak belum mengerti sepenuhnya tentang tujuan dan pelaksanaan program, penyeleksian calon penerima bantuan terjadi beberapa penyimpangan, pembentukan kelompok tani tidak berdasarkan aturan yang ditetapkan, penyusunan rencana usaha kelompok dan penentuan bangsa serta spesifikasi ternak tidak melibatkan anggota kelompok, spesifikasi ternak yang diterima penggaduh tidak sesuai dengan ketentuan. Pada tahap implementasi, terjadi penyalahgunaan pemanfaatan dana, spesifikasi ternak dan pembebanan biaya kepada anggota kelompok, terjadi perbedaan mekanisme perguliran ternak bantuan di masingmasing desa. Peningkatan populasi sapi potong yang diharapkan program belum mencapai target yang ditentukan. Kesimpulan dari penelitian ini adalah pelaksanaan program pengembangan agribisnis peternakan di Kabupaten Sekadau belum optimal.

(Kata kunci: Karakteristik sosial demografi, Pelaksanaan program, Sapi potong)

\section{ABSTRACT}

Objectives of this research were to analyze the characteristic of social demography of farmer's participated in program and to carryout assessment. The implementation of agribusiness development program of beef cattle farming in Sekadau Regency. This research was conducted from August until October 2009. One hundred and eight farmers participated in the program as respondents, selected by proportionate random sampling method, from five villages, locations of the program of livestock grant. Data of increasing population, number of investor, social demography characteristic of respondents and income contribution from beef cattle farming were analyzed by quantitative descriptive. Data of program implementation process, input and program implementation were analyzed by qualitative descriptive. Result showed that the beef cattle population increased about 152 heads and the investor increased about 58 investors, respondent characteristics were age was $42.30 \pm 5.87$ years old, majority of education level was on elementary school $43.52 \%$, length of farming experience was $1.61 \pm 1,20$ years, averages of cattle owning $1.88 \pm 1.05$ Livestock Unit (LU), the number of family support 3.36 1.15 head, and averages of time allocation of farming $0.078 \pm 0.082 \mathrm{HOK} / \mathrm{LU} /$ day, average income contribution from beef cattle farming was rangery from 8.21-24.09\%. Program's socialization in Sekadau Regency was not effective because many of the farmers had not fully understood about the objective and the implementation of the program, there was a distortion on the selection of farmers who received livestock grant, farmer groups were not established based on the rule, were not involved members the arrangement of group business plan, breed determination and cattle specification, cattle's specifications were not

\footnotetext{
* Korespondensi (corresponding author): Telp. + 62821

5867 2000, E-mail: prosmael@yahoo.co.id
} 
suitable with the condition. On the implementation step, there was a distortion of the fund, cattle specification and cost burden to the member, difference on mechanism of livestock grant revolving in each village. The increase of beef cattle population had not reached the determined target. It could be concluded that the implementation of agribusiness development program in Sekadau Regency has not been optimal.

(Keywords: Social demography characteristic, Program implementation, Beef cattle)

\section{Pendahuluan}

Ternak sapi, khususnya sapi potong merupakan salah satu sumber daya penghasil bahan makanan berupa daging, selain itu sapi potong juga bisa memberikan berbagai macam kontribusi seperti pupuk dan sebagai ternak kerja (Sugeng, 2003). Dengan demikian pengembangan ternak sapi potong penting untuk ditingkatkan melalui pengembangan populasi sapi potong.

Dalam rangka pengembangan sapi potong peran keluarga peternak di pedesaan tidak dapat diabaikan. Mereka harus didukung karena untuk mengembangkan usahanya masih terkendala oleh modal dan keterampilan. Untuk itu diharapkan adanya perhatian pemerintah melalui programprogram dan kebijakan yang terkait dengan pengembangan usaha peternakan dengan memberikan bantuan modal usaha. Kebijakan dan programprogram pemerintah tersebut telah diimplementasikan secara nasional maupun daerah seperti di Provinsi Kalimantan Barat dilaksanakan dengan mengacu pada program pembangunan peternakan nasional dan berorientasi pada kebutuhan langsung masyarakat utamanya yang bersifat pemberdayaan ekonomi kerakyatan. Program bantuan tersebut untuk mengatasi kekurangan modal peternak yang diberikan berupa ternak sapi dan disalurkan melalui pola gaduhan.

Usaha untuk menunjang pembangunan peternakan di Provinsi Kalimantan Barat dengan meluncurkan program bantuan ke beberapa dinas peternakan, salah satunya Dinas Pertanian, Perikanan dan Peternakan Kabupaten Sekadau melalui program pengembangan agribisnis peternakan tahun 2005. Sumber dana program pengembangan agribisnis peternakan sapi potong ini berasal dari Anggaran Pendapatan dan Belanja Daerah (APBD) provinsi sebesar Rp. 720.000.000,00 dan APBD kabupaten sebesar Rp. 555.000.000,00. Pelaksanaannya berupa bantuan usaha ekonomi produktif kepada kelompok tani sasaran dengan pola Bantuan Pinjaman Langsung Masyarakat (BPLM). Dana tersebut dimanfaatkan untuk pengadaan ternak sapi dan penguatan modal kelompok yang kemudian disebarkan ke beberapa lokasi. Tujuan program tersebut adalah meningkatkan populasi ternak sapi potong, memberdayakan kelompok-kelompok tani yang kekurangan modal dalam pengembangan usahanya, dan menciptakan lapangan pekerjaan.

Dana tersebut dimanfaatkan untuk pengadaan ternak sapi dan penguatan modal kelompok yang kemudian disebarkan ke beberapa lokasi. Total keseluruhan ternak yang disebar adalah 302 ekor dengan perincian, pada tahun 2005 berjumlah 180 ekor dan tahun 2007 berjumlah 122 ekor. Ternak disebar pada 5 desa yaitu, Seberang Kapuas, Peniti, Kumpang Bis, Padak, dan Engkresik. Setiap desa mendapat bantuan ternak sapi dengan jumlah yang berbeda, Desa Seberang kapuas mendapat bantuan sejumlah 60 ekor untuk 30 peternak, Desa Peniti mendapat 60 ekor untuk 30 peternak, Desa Kumpang Bis mendapat 60 ekor untuk 30 peternak, Desa Padak mendapat 60 ekor untuk 28 peternak, dan Desa Engkresik mendapat 62 ekor untuk 28 peternak.

Salah satu aturan yang ditetapkan dalam Petunjuk Teknis proyek pengembangan agribisnis peternakan yang ditetapkan oleh Dinas Pertanian, Perikanan dan Peternakan Kabupaten Sekadau, mengenai persyaratan calon penggaduh yaitu: a) berada dalam satu kelompok, b) bersedia mengikuti arahan dan bimbingan dari petugas, c) harus mentaati peraturan yang disepakati baik tentang perguliran induk,maupun aturan lainnya, d) mempunyai pengalaman dan keterampilan serta kemampuan memelihara ternak, dan e) anggota kelompok diwajibkan masuk lembaga keuangan mikro.

Selain program pengembangan agribisnis peternakan sapi potong, sebelumnya telah ada program untuk peningkatan populasi ternak kambing yang dilaksanakan di Kabupaten Sekadau. Program peningkatan populasi ternak kambing yang dilaksanakan tidak sesuai dengan harapan, karena pada saat penyeleksian penerima bantuan kurang memperhatian karakteristik sosial demografi calon penerima bantuan seperti pengalaman beternak, dan pendidikan peternak kurang diperhatikan. Pendampingan serta pengawasan program juga kurang maksimal dilakukan. Untuk itu adanya dugaan pada program pengembangan agribisnis peternakan yang dilaksanakan di Kabupaten Sekadau terjadi penyimpangan serupa yang dilakukan seperti yang berkaitan dengan karakteristik sosial demografi penerima bantuan serta pada pelaksanaan program. 
Berdasarkan latar belakang yang telah dikemukakan maka permasalahan dirumuskan sebagai berikut: Seperti apakah karakteristik sosial demografi peternak yang menerima bantuan sapi potong di Kabupaten Sekadau? Apakah pelaksanaan program pengembangan agribisnis peternakan sapi potong di Kabupaten Sekadau sudah sesuai dengan prosedur (rancangan operasional)?

Berdasarkan permasalahan yang dirumuskan maka dilakukan penelitian yang bertujuan untuk mengkaji karakteristik sosial demografi peternak penerima bantuan sapi potong dan menilai proses pelaksanaan program pengembangan agribisnis peternakan sapi potong di Kabupaten Sekadau.

Manfaat yang diharapkan dari penelitian ini adalah: 1) Sebagai bahan informasi bagi peternak untuk memanfaatkan bantuan ternak agar dapat meningkatkan pendapatan usaha taninya; 2) Sebagai bahan masukan kepada penentu kebijakan Pemerintah Daerah Kabupaten Sekadau untuk perbaikan program yang akan datang; 3) Sebagai sumber informasi dan kontribusi dalam pengembangan ilmu pengetahuan bagi semua pihak serta peneliti lainnya terhadap pelaksanaan program perkembangan sapi potong masa yang akan datang.

\section{Metode Penelitian}

\section{Waktu dan lokasi penelitian}

Penelitian ini dilaksanakan pada bulan Agustus sampai dengan bulan Oktober 2009. Lokasi penelitian meliputi 5 desa yang merupakan daerah penyebaran ternak sapi potong di Kabupaten Sekadau yaitu Desa Seberang Kapuas, Desa Peniti, Desa Kumpang Bis, Desa Padak, dan Desa Engkresik.

\section{Jenis data dan teknik pengumpulan data}

Jenis data yang dikumpulkan adalah data primer dan data sekunder. Data primer merupakan data yang berkaitan dangan tujuan penelitian yang meliputi proses pelaksanaan, input, implementasi dan harapan program. Metode pengambilan data primer dilakukan dengan metode survei melalui wawancara langsung dengan responden menggunakan instrumen yaitu kuesioner. Data sekunder meliputi prosedur pelaksanaan program, jumlah kelompok peternak penerima bantuan, populasi ternak sapi, keadaan umum wilayah penelitian, keadaan penduduk Kabupaten Sekadau, kondisi peternakan di Kabupaten Sekadau dan data lain yang berhubungan dengan penelitian. Data sekunder diperoleh dari berbagai instansi seperti Dinas Peternakan, Kantor Statistik, dan instansi lain yang terkait.

\section{Responden}

Untuk menentukan jumlah responden dalam penelitian ini digunakan metode proportionate random sampling dengan menggunakan rumus menurut Yamane cit. Guntoro dan Udomsade (2005) sebagai berikut:

Keterangan:

$$
\mathrm{n}=\frac{\mathrm{N}}{1+\mathrm{Ne}^{2}}
$$

$\mathrm{n}=$ sampel

$\mathrm{N}=$ populasi

$\mathrm{e}=$ tingkat error populasi yang diharapkan $5 \%$.

Penentuan responden dilakukan secara convenience random sampling. Dari hasil perhitungan dengan rumus di atas didapat sampel responden sebanyak 108 responden. Jumlah populasi sampel tersaji pada Tabel 1.

\section{Analisis data}

Data peningkatan populasi ternak, jumlah peternak/penggaduh baru, karakterisktik responden dan kontribusi penerimaan dianalisis secara deskriptif kuantitatif. Data hasil wawancara seperti: sosialisasi program, seleksi calon penerima bantuan, pembentukan kelompok tani, penyusunan rencana usaha kelompok, penentuan bangsa sapi potong, jumlah dan spesifikasi ternak sapi yang diterima penggaduh, proses pencairan dana, pemanfaatan dana, proses pengadaan bakalan, perguliran bantuan, perguliran ternak kepada kelompok baru, pendampingan program dan monitoring pelaksanaan dianalisis secara deskriptif kualitatif.

Tabel 1. Jumlah populasi sampel yang digunakan dalam penelitian (the number of sample population used in the research)

\begin{tabular}{llcc}
\hline \hline Kecamatan (district) & Desa (village) & Populasi (population) (N) & Sampel (sample) (n) \\
\hline Belitang Hilir & Kumpang Bis & 30 & 22 \\
Sekadau Hilir & Seberang Kapuas & 30 & 22 \\
& Peniti & 30 & 22 \\
\multirow{2}{*}{ Belitang } & Engkresik & 28 & 21 \\
\hline \multicolumn{2}{c}{ Jumlah $($ total $)$} & 28 & 21 \\
\hline
\end{tabular}




\section{Hasil dan Pembahasan}

\section{Keadaan umum wilayah penelitian}

Kabupaten Sekadau adalah salah satu kabupaten di Provinsi Kalimantan Barat yang merupakan kabupaten pemekeran dari Kabupaten Sanggau. Luas daerah Kabupaten Sekadau adalah 544.430 hektar dengan rerata kepadatan penduduk 32 jiwa per $\mathrm{km}^{2}$. Batas wilayah Kabupaten Sekadau sebelah utara berbatasan dengan Kabupaten Sintang, sebelah selatan berbatasan dengan Kabupaten Ketapang, sebelah timur berbatasan dengan Kabupaten Sintang, sebelah barat berbatasan dengan Kabupaten Sanggau. Secara administratif pemerintahan Kabupaten Sekadau terbagi atas tujuh kecamatan yaitu Kecamatan Nanga Mahap, Kecamatan Nanga Taman, Kecamatan Sekadau Hilir, Kecamatan Sekadau Hulu, Kecamatan Belitang Hilir, Kecamatan Belitang, dan Kecamatan Belitang Hulu. Pada umumnya keadaan topografi Kabupaten Sekadau terdiri atas wilayah dengan keadaan lereng antara dua persen sampai dengan lima belas persen (325,210 ha), sedangkan kelas lereng yang melebihi empat puluh persen sebesar 32.320 ha (Badan Pusat Statistik Kabupaten Sekadau, 2008).

\section{Keadaan penduduk di Kabupaten Sekadau}

Jumlah penduduk di Kabupaten Sekadau pada tahun 2007 sebesar 175.529 jiwa, dengan jumlah rumah tangga 38.500 kepala keluarga (kk). Tabel 2 menunjukkan bahwa jumlah penduduk Kabupaten Sekadau menurut kelompok umur yang paling banyak pada umur 10-19 tahun sebanyak 39.687 jiwa $(22,63 \%)$ dan sebagian besar penduduk Kabupaten Sekadau yang berumur 15 tahun ke atas bekerja pada sektor pertanian sebanyak 77.723 jiwa, sektor industri sebanyak 4.827 jiwa dan sektor jasa sebanyak 11.743 jiwa (Badan Pusat Statistik Kabupaten Sekadau, 2008).

\section{Kondisi peternakan di Kabupaten Sekadau}

Perkembangan populasi ternak di Kabupaten Sekadau dari tahun 2005 sampai dengan 2008 tersaji pada Tabel 3. Tabel 3 menunjukkan bahwa pada tahun 2008 populasi sapi potong di Kabupaten Sekadau meningkat $4,22 \%$ dari tahun 2007 , diikuti peningkatan ternak lainnya seperti ternak kambing meningkat $7,56 \%$, ternak babi meningkat $14,29 \%$, ternak itik meningkat $203,32 \%$, ternak ayam buras mengalami peningkatan populasi sebanyak $1,47 \%$. Sedikitnya peningkatan populasi ayam buras dikarenakan terjadi wabah penyakit yang menyerang ternak ayam buras maupun ayam ras pedaging. Populasi ayam ras pedaging pada tahun 2007 berjumlah 400.000 ekor, mengalami penurunan sebesar $75 \%$ menjadi 100.000 ekor pada tahun 2008.

Peningkatan populasi sapi potong dikarenakan adanya program dan terjadi peningkatan pemeliharan sapi potong yang dilakukan oleh masyarakat. Dalam rangka pengembangan peternakan sapi potong, pemerintah Kabupaten Sekadau melalui Dinas Pertanian, Perikanan dan Peternakan secara intensif melakukan perbaikan sistem pemeliharaan dari ekstensif menjadi intensif dan melakukan pengawasan pemotongan dan penjualan betina produktif keluar daerah serta mengaktifkan program Inseminasi Buatan (IB) dengan mengirim penyuluhan lapangan untuk pelatihan inseminator ke Balai Inseminasi Buatan (BIB) Singosari.

\section{Karakteristik peternak}

Umur peternak. Rerata umur peternak di Kabupaten Sekadau adalah 42,30 $\pm 5,87$ tahun dengan kisaran 30-55 tahun. Kisaran umur tersebut dapat dikategorikan umur yang produktif, sehingga masih memungkinkan untuk mengembangkan dan mengelola usaha peternakannya.

Tingkat pendidikan peternak. Hasil penelitian menunjukkan tingkat pendidikan peternak cukup tinggi yaitu yang berpendidikan SLTA dan

Tabel 2. Klasifikasi penduduk Kabupaten Sekadau berdasarkan umur dan jenis kelamin (classification of Sekadau Regency's people based on age and gender)

\begin{tabular}{|c|c|c|c|c|c|c|}
\hline \multirow{2}{*}{$\begin{array}{l}\text { Umur (tahun) } \\
\text { (age (year)) }\end{array}$} & \multicolumn{2}{|c|}{ Pria (male) } & \multicolumn{2}{|c|}{ Wanita (female) } & \multicolumn{2}{|c|}{$\begin{array}{l}\text { Total pria dan wanita (total male and } \\
\text { female) }\end{array}$} \\
\hline & $\begin{array}{c}\text { Jumlah } \\
\text { (total) }\end{array}$ & $\begin{array}{l}\text { Persen } \\
\text { (percent) }\end{array}$ & $\begin{array}{c}\text { Jumlah } \\
\text { (total) }\end{array}$ & $\begin{array}{l}\text { Persen } \\
\text { (percent) }\end{array}$ & Jumlah (total) & Persen (percent) \\
\hline $0-9$ & 14.629 & 8,33 & 17.392 & 9,91 & 32.021 & 18,28 \\
\hline $10-19$ & 20.755 & 11,82 & 18.932 & 10,79 & 39.687 & 22,63 \\
\hline $20-29$ & 14.967 & 8,53 & 16.947 & 9,69 & 31.914 & 18,22 \\
\hline $30-39$ & 13.513 & 7,71 & 15.266 & 8,70 & 28.779 & 16,42 \\
\hline $40-49$ & 12.102 & 6,71 & 9.441 & 5,38 & 21.543 & 12,09 \\
\hline$\geq 50$ & 13.709 & 7,81 & 7.876 & 4,50 & 21.585 & 12,35 \\
\hline Sub total & 89.675 & 50,98 & 85.854 & 49,02 & 175.529 & 100,00 \\
\hline
\end{tabular}

Sumber: Badan Pusat Statistik Kabupaten Sekadau, 2008 (Central Board of Statistic, Sekadau Regency, 2008). 
Tabel 3. Populasi ternak di Kabupaten Sekadau (cattle population in Sekadau Regency)

\begin{tabular}{|c|c|c|c|c|}
\hline \multirow{2}{*}{ Jenis ternak (type of livestock) } & \multicolumn{4}{|c|}{ Jumlah (ekor) (total (head)) } \\
\hline & 2005 & 2006 & 2007 & 2008 \\
\hline Sapi potong (beef cattle) & 14.895 & 15.144 & 15.583 & 16.241 \\
\hline Kambing (goat) & 4.541 & 4.677 & 4.817 & 5.180 \\
\hline Babi (pig) & 25.305 & 26.012 & 23.714 & 27.104 \\
\hline Ayam buras (mative chicken) & 300.649 & 305.500 & 310.388 & 314.954 \\
\hline Ayam ras pedaging (broiler) & 300.000 & 360.000 & 400.000 & 100.000 \\
\hline Itik $(d u c k)$ & 8.942 & 9.200 & 4.458 & 13.522 \\
\hline
\end{tabular}

Sumber: Dinas Pertanian, Perikanan dan Peternakan Kabupaten Sekadau, 2008 (Agricultural, Fisheries and Animal Production Department of Sekadau Regency, 2008).

D3/S-1 mencapai 32,41\%, SD 43,53\% dan SLTP sebesar $24,07 \%$. Meskipun rerata pendidikan peternak tergolong cukup tinggi namun pola pemeliharaan ternak yang diterapkan masih tergolong tradisional dan ekstensif. Hal ini memungkinkan kurangnya kontrol terhadap reproduksi dan pakan ternak.

Pengalaman beternak. Pada umumnya peternak penggaduh di Kabupaten Sekadau mempunyai pengalaman beternak yang masih kurang, bahkan sebagian peternak tidak mempunyai pengalaman beternak, rerata pengalaman beternak

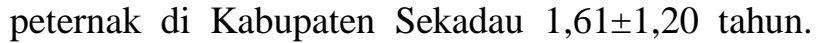
Kurangnya pengalaman beternak yang dimiliki peternak penggaduh di Kabupaten Sekadau dapat mempengaruhi berjalannya program yang dilaksanakan, karena dengan pengalaman beternak yang kurang maka peternak tidak mengerti tentang tatalaksana pemeliharaan ternak yang baik dan sulit mengatasi permasalahan yang ditemui dalam beternak.

Jumlah kepemilikan ternak. Rerata tingkat kepemilikan sapi potong masing-masing anggota kelompok tani di Kabupaten Sekadau 1,88 $\pm 1,05$ UT. Jumlah kepemilikan ternak yang ada di daerah penelitian tergolong rendah hal ini seiring dengan pendapat Aziz (1993) bahwa pemilikan ternak pada masing-masing peternak bervariasi karena tergantung dari modal yang dimiliki. Rendahnya jumlah kepemilikan ternak dikarenakan perkembangbiakan ternak sapi bantuan lambat. Hal ini terjadi karena peternak kurang mempunyai pengalaman beternak serta pengetahuan mengenai manajemen pemeliharaan dan beberapa faktor lainnya seperti kurangnya sapi pejantan bantuan di tiap-tiap lokasi penyebaran.

Jumlah tanggungan keluarga. Tenaga kerja yang digunakan peternak untuk mengusahakan sapi potong berasal dari tenaga kerja keluarga, hal ini dikarenakan skala kepemilikan ternak rerata hanya $1,88 \pm 1,05$ UT dan sistem pemeliharaannya masih tradisional. Tenaga kerja yang digunakan peternak untuk mengusahakan sapi potong pada penelitian ini berasal dari tenaga kerja keluarga, hal ini seiring dengan pendapat Mubyarto (1989) cit. Nazlah (2008) menyatakan bahwa tenaga kerja dalam pertanian maupun peternakan tradisional berbeda dengan tenaga kerja dalam perusahaan. Pertanian dan peternakan tradisional dalam usaha taninya sebagian besar menggunakan tenaga kerja keluarga.

Alokasi waktu beternak. Hasil penelitian menunjukkan bahwa alokasi waktu terbanyak yaitu kegiatan menggembalakan ternak. Untuk Desa Padak sebesar 0,30 HOK/UT/hari $(54,54 \%)$, Desa Engkresik sebesar 0,027 HOK/UT/hari (40,91\%), Desa Seberang Kapuas sebesar 0,028 HOK/UT/hari (37,33\%), Desa Kumpang Bis 0,043 HOK/UT/hari $(37,07 \%)$, dan Desa Peniti sebesar 0,010 HOK/UT/hari (12,99\%).

Desa Peniti menggunakan waktu menggembala ternak paling kecil yaitu $12,99 \%$, hal ini dikarenakan peternak di Desa Peniti kadang-kadang menggembalakan ternaknya pada siang hari dan pada sore harinya dimasukkan kandang. Waktu menggembalakan yang paling banyak yaitu Desa Padak sebesar 54,54\% dan mencari rumput sebesar $21,82 \%$. Kondisi ini dikarenakan sebagian besar peternak di Desa Padak memelihara ternaknya tanpa dikandangkan di area perkebunan kelapa sawit dan hanya sebagian kecil peternak yang menggembalakan ternaknya pada siang hari dan ketika menjelang sore hari dimasukkan ke kandang.

\section{Proses pelaksanaan program pengembangan sapi potong}

Sosialisasi program. Tujuan sosialisasi program kepada kelompok penerima bantuan dilakukan untuk menyamakan persepsi antara Dinas Pertanian, Perikanan dan Peternakan Kabupaten Sekadau dengan anggota kelompok tani. Dari hasil penelitian ditemukan perbedaan proses sosialisasi program untuk masing-masing desa. Sosialisasi program yang dilakukan di Desa Peniti, Desa Engkresik, Desa Kumpang Bis, dan Desa Seberang Kapuas berbeda dengan di Desa Padak. Sosialisasi di keempat desa tersebut dilakukan dengan cara mengumpulkan seluruh anggota kelompok di balai desa atau di rumah ketua kelompok. Sosialisasi 
program dilakukan oleh tim teknis kabupaten dan penyuluh lapangan tentang tujuan, prinsip-prinsip dasar, tahap kegiatan, dan aturan-aturan pokok program. Metode sosialisasi yang digunakan adalah komunikasi tatap muka (anggota kelompok tani mendengarkan ceramah dari tim teknis beserta rombongan), kegiatan sosialisasi tersebut dilakukan 2-3 kali di setiap desa.

Sosialisasi di Desa Padak dilakukan dengan mengumpulkan masyarakat beserta anggota kelompok tani di balai desa untuk mengikuti pertemuan membahas program bantuan pemerintah seperti program pertanian dan peternakan. Setelah mencapai kesepakatan, masyarakat Desa Padak memilih program peternakan. Selanjutnya tim teknis kabupaten dan penyuluh lapangan melakukan sosialisasi mengenai hal-hal yang berkaitan dengan program tersebut, sosialisasi yang dilakukan di Desa Padak sebanyak 3 kali.

Terjadinya perbedaan sosialisasi program di Desa Padak dengan empat desa lainnya dikarenakan Desa Padak sama sekali belum pernah mendapatkan bantuan program pertanian maupun peternakan. Sosialisasi program yang dilakukan oleh tim teknis kabupaten kurang dapat diterima dengan baik oleh peternak, hal ini dapat dilihat dari temuan di lapangan bahwa sebagian besar peternak penerima bantuan tidak mengerti mengenai tujuan dan langkah-langkah program. Temuan tersebut adalah 1) Peternak tidak mengerti tujuan dari program; 2) Peternak tidak mengerti langkah-langkah program seperti perguliran bantuan ternak kepada kelompok baru dan penanganan ternak bantuan jika ada yang majir; dan 3) Peternak bingung dengan kriteria mengenai ganti rugi ternak, hal ini seperti yang terjadi di Desa Kumpang Bis, salah seorang peternak dianggap menyalahgunakan ternak dan diharuskan mengganti rugi ternak bantuan miliknya yang mati dikarenakan terlilit tali saat di kandang.

Kondisi ini disebabkan pada saat sosialisasi program banyak masyarakat yang tidak hadir karena waktu sosialisasi yang tidak tepat, sehingga menyebabkan peternak tidak mengerti maksud dan tujuan serta aturan-aturan program. Hal tersebut dapat diatasi dengan pendampingan dan penyuluhan yang efektif.

Seleksi calon penerima bantuan program sapi potong. Kriteria-kriteria yang digunakan untuk menyeleksi calon penerima bantuan pada rencana operasional dan kriteria seleksi calon penerima bantuan yang dilaksanakan di lapangan tersaji pada Tabel 4.

Tabel 4 menunjukkan kriteria calon penerima bantuan di Desa Kumpang Bis tidak berdasarkan kriteria yang telah ditetapkan. Kondisi tersebut disebabkan tim teknis kabupaten langsung menunjuk seorang warga yang dianggap mampu untuk membentuk kelompok dan ditetapkan sebagai ketua kelompok untuk menyeleksi calon penerima bantuan. Hal ini menyebabkan pemilihan calon penerima bantuan ditentukan oleh ketua kelompok.

Kriteria seleksi yang paling banyak tidak dilaksanakan di lapangan adalah kriteria nomor satu tentang penerima bantuan berada dalam satu kelompok, karena banyak anggota kelompok berdomisili di wilayah yang berbeda. Kriteria seleksi nomor dua juga banyak yang tidak diterapkan yaitu tentang calon penerima bantuan harus memiliki pengalaman beternak. Kenyataan di lapangan mayoritas calon penerima bantuan hanya memiliki keahlian bertani dan belum pernah memelihara sapi potong. Kriteria seleksi nomor lima tentang wajib masuk lembaga keuangan desa/mikro juga hampir seluruhnya tidak dilaksanakan di lapangan karena di lokasi tidak terdapat lembaga keuangan mikro.

Tabel 4. Kriteria seleksi calon penerima bantuan (selection criteria of grant receiver candidate)

\begin{tabular}{lccccc}
\hline \hline \multirow{2}{*}{ Desa (village) } & \multicolumn{5}{c}{ Kriteria seleksi (selection criteria) } \\
\cline { 2 - 6 } & 1 & 2 & 3 & 4 & 5 \\
\hline Engkresik & - & $*$ & - & $*$ & - \\
Kumpang Bis & - & - & - & - & $*$ \\
Peniti & - & $*$ & - & $*$ & - \\
Padak & $*$ & $*$ & - & $*$ \\
Seberang Kapuas & - & $*$ & -
\end{tabular}

1 Penerimaan bantuan berada dalam satu kelompok (recipient in group)

2 Bersedia mengikuti arahan dan bimbingan dari petugas (have a will to follow the guidance of government fungsionary)

3 Harus sudah memiliki pengalaman beternak sapi (have an experience in raising cattle)

4 Harus bersedia mentaati tata peraturan yang disepakati (have a will to obey the agreement)

5 Wajib masuk lembaga keuangan desa/mikro (have to join the financial institution)

* Dilaksanakan di lapangan/sesuai kriteria dalam rencana operasional program (implemented as operational plans of program)

- Tidak dilakukan di lapangan/tidak sesuai dengan kriteria yang ada dalam rencana operasional program (not implemented as operational plans of program) 
Penyeleksi calon penerima bantuan sapi potong di Kabupaten Sekadau dinilai tidak sesuai dengan kriteria yang ditetapkan dalam rencana operasional, serta seharusnya kriteria seleksi pada rencana operasional mengenai calon penerima bantuan harus petani yang benar-benar mempunyai keinginan untuk memelihara ternak perlu ditambahkan, karena kriteria yang berkaitan dengan hal tersebut bila diterapkan dengan baik akan sangat mempengaruhi keberhasilan program. Kondisi ini dikarenakan tidak ada pengawasan atau pendampingan dari tim teknis kabupaten dan penyuluh lapangan.

Pembentukan kelompok tani. Dari hasil penelitian, proses pembentukan kelompok tani pada umumnya dilakukan oleh kelompok itu sendiri dan dilakukan dengan cara yang berbeda. Ada kelompok yang sudah terbentuk sebelum adanya program dan ada yang terbentuk ketika adanya program. Desa Engkresik dan Desa Kumpang Bis membentuk kelompok tani ketika adanya program dan printisnya seseorang yang langsung ditunjuk oleh tim teknis kabupaten. Walaupun desa tersebut belum ada kelompok tani, namun tim teknis kabupaten menilai desa tersebut layak untuk menerima bantuan karena berada pada kawasan hamparan kebun kelapa sawit, jagung dan sayuran. Dampak dari pengorganisasian kelompok bentukan baru menyebabkan banyak terjadi ketidakcocokan antar anggota kelompok, karena baru saling mengenal yang dapat mempengaruhi kelompok tersebut dalam mencapai tujuan.

Penyusunan rencana usaha kelompok. Penyusunan rencana usaha kelompok (RUK) pada pelaksanaan program pengembangan peternakan sapi potong di Kabupaten Sekadau di setiap kelompok tani berbeda-beda. Kelompok tani Desa Peniti, Seberang Kapuas dan Kumpang Bis tidak terlibat dalam penyusunan RUK karena telah disusun oleh tim teknis kabupaten. Masing-masing ketua kelompok tani hanya menandatangani RUK yang telah disusun oleh tim teknis kabupaten tersebut. Penyusunan RUK di Desa Peniti, Seberang Kapuas, dan Kumpang Bis dinilai tidak sesuai aturan, karena tidak melibatkan kelompok serta perincian-perincian anggaran telah ditetapkan oleh tim teknis kabupaten. Tim teknis kabupaten tidak melibatkan kelompok pada saat penyusunan RUK karena mereka menganggap bahwa perincianperincian mengenai keperluan untuk usaha peternakan seperti obat-obatan, vitamin dan hormon gertak birahi kelompok tidak mengetahuinya secara pasti. Sebaiknya pada penyusunan RUK tim teknis dan kelompok bersama-sama membahas perincian rencana kelompok, supaya anggota kelompok juga dapat mengerti mengenai perincian untuk usaha peternakan.

Penyusunan RUK di Desa Engkresik dan Padak melibatkan anggota kelompok. Tim teknis Kabupaten Sekadau menyusun rancangan RUK kemudian rancangan tersebut diserahkan kepada kelompok tani untuk direvisi/dibahas secara bersamasama. Setelah disepakati kelompok, RUK diserahkan kembali kepada tim teknis kabupaten untuk proses selanjutnya.

Desa Engkresik dan Padak ketika penyusunan RUK melibatkan anggota kelompok sehingga anggota kelompok bisa mengerti dan mempunyai pengalaman mengenai perincian untuk usaha peternakan secara jelas.

Penentuan bangsa, jumlah, dan spesifikasi ternak. Data pada Tabel 5 menunjukkan bahwa umur dan berat badan ternak yang diterima kelompok tani Desa Kumpang Bis, Peniti, Padak dan Seberang Kapuas tidak diketahui. Untuk kelompok tani Desa Engkresik dan Desa Seberang Kapuas mengenai umur dan tinggi gumba diketahui tetapi tidak sesuai dengan spesifikasi yang ditetapkan. Jumlah ternak sapi yang diterima setiap peternak juga berbeda-beda, ada peternak yang menerima dua ekor betina dan ada peternak yang menerima tiga ekor sapi terdiri dari satu ekor jantan dan dua ekor betina. Hal ini dikarenakan adanya kecurangan yang dilakukan tim pengadaan ternak seperti harga dinaikkan dari yang telah ditentukan dan spesifikasi ternak yang dibeli tidak sesuai dengan harga tersebut. Dampak dari kecurangan yang dilakukan menyebabkan peternak merasa dirugikan, karena sampai program berjalan selama empat tahun hingga saat penelitian masih banyak ternak yang belum bunting. Peternak telah mengusulkan agar ternak-ternak yang belum bunting dilelang dan hasil dari pelelangan ternak tersebut untuk membeli ternak yang baru. Usulan tersebut diterima, namun hasil dari pelelangan ternak tersebut sampai saat penelitian dilakukan belum digunakan untuk membeli ternak baru.

\section{Implementasi}

Proses pencairan dana. Kelompok tani masing-masing desa mengatakan bahwa kelemahan dari sistem pencairan dana yang dilakukan adalah tidak melibatkan perwakilan anggota kelompok maupun bendahara dalam proses pencairan dana, karena jumlah dana yang dicairkan sesuai dengan yang tertera pada RUK dan dana yang dicairkan langsung ditransfer kepada rekening kelompok. Kelebihan dari sistem pencairan dana yang dilakukan tergolong cepat, hal ini dapat dilihat dari Desa Seberang Kapuas dan Kumpang Bis melakukan 
Tabel 5. Jumlah dan spesifikasi ternak yang diterima masing-masing peternak (numbers and specification of cattle accepted by each farmer)

\begin{tabular}{|c|c|c|c|c|c|c|c|}
\hline \multirow{3}{*}{$\begin{array}{c}\text { Desa } \\
\text { (village) }\end{array}$} & \multirow{3}{*}{$\begin{array}{c}\text { Jumlah } \\
\text { peternak } \\
\text { (orang) } \\
\text { (number of } \\
\text { farmer } \\
\text { (person)) }\end{array}$} & \multirow{2}{*}{\multicolumn{2}{|c|}{$\begin{array}{c}\text { Jumlah sapi (ekor) } \\
\text { (number of cattle } \\
\text { (head)) }\end{array}$}} & \multicolumn{4}{|c|}{ Spesifikasi (specification) } \\
\hline & & & & \multirow{2}{*}{$\begin{array}{l}\text { Bangsa } \\
\text { sapi } \\
\text { (breed) }\end{array}$} & \multirow{2}{*}{$\begin{array}{l}\text { Umur (bulan) } \\
\text { (age (month)) }\end{array}$} & \multirow{2}{*}{$\begin{array}{l}\text { Berat badan }(\mathrm{kg}) \\
(\text { body weight }(\mathrm{kg}))\end{array}$} & \multirow{2}{*}{$\begin{array}{l}\text { Tinggi gumba } \\
(\mathrm{cm})(\text { wither } \\
\text { height }(\mathrm{cm}))\end{array}$} \\
\hline & & $\begin{array}{c}\text { Jantan } \\
\text { (bull) }\end{array}$ & $\begin{array}{c}\text { Betina } \\
(\text { cow })\end{array}$ & & & & \\
\hline \multirow[t]{2}{*}{ Engkresik } & 25 & & 2 & Sapi Bali & $10 \mathrm{~s} / \mathrm{d} 12$ & $\mathrm{x}$ & $\mathrm{x}$ \\
\hline & 3 & $\overline{1}$ & 2 & Sapi Bali & $10 \mathrm{~s} / \mathrm{d} 12$ & $\mathrm{x}$ & $\mathrm{x}$ \\
\hline Kumpang Bis & 30 & _ & 2 & Sapi Bali & $\mathrm{x}$ & $\mathrm{x}$ & 103 \\
\hline Peniti & 30 & _- & 2 & Sapi Bali & $\mathrm{x}$ & $\mathrm{x}$ & 103 \\
\hline \multirow[t]{2}{*}{ Padak } & 26 & - & 2 & Sapi Bali & $\mathrm{x}$ & $\mathrm{x}$ & $90 \mathrm{~s} / \mathrm{d} 100$ \\
\hline & 2 & 1 & 2 & Sapi Bali & $\mathrm{x}$ & $\mathrm{x}$ & 91 s/d 100 \\
\hline $\begin{array}{l}\text { Seberang } \\
\text { Kapuas }\end{array}$ & 30 & - & 2 & Sapi Bali & $\mathrm{x}$ & $\mathrm{x}$ & 103 \\
\hline
\end{tabular}

$\mathrm{x}$ Tidak diketahui (unknown)

- Tidak menerima sapi jantan (did not receive bulls)

pencairan dana seminggu setelah mengajukan RUK, Desa Peniti melakukan pencairan dana sebulan setelah mengajukan RUK, Desa Engkresik dan Padak mencairkan dana empat bulan setelah mengajukan RUK.

Perbedaan lama waktu pencairan dana Desa Peniti, Desa Seberang Kapuas dan Desa Kumpang Bis disebabkan keaktifan masing-masing ketua kelompok berkoordinasi dengan tim teknis kabupaten, hal ini berkenaan dengan Petugas Pemeriksa Keuangan (PPK) dan waktu kelompok tani mengajukan RUK kepada tim teknis kabupaten. Sedangkan lama waktu pencairan dana untuk Desa Engkresik dan Desa Padak dikarenakan dana yang seharusnya diterima kedua desa tersebut dialokasikan ke desa lainnya untuk pengembangan ternak kambing.

Pemanfaatan dana. Dari hasil penelitian ditemukan beberapa penyimpangan pada kelompok tani mengenai pemanfaatan dana bantuan seperti adanya biaya pembuatan papan nama kelompok dalam perincian tetapi tidak ada di lokasi. Penyimpangan juga dilakukan oleh tim pengadaan ternak seperti pembelian ternak tidak sesuai dengan spesifikasi yang ditentukan dan adanya perbedaan harga pembelian ternak dengan harga yang telah ditentukan. Penyimpangan pemanfaatan dana terbesar banyak terjadi pada pengadaan ternak. Harga sapi dinaikkan dari harga yang telah ditentukan, hal ini terjadi hampir di semua kelompok tani. Di kelompok tani Desa Engkresik, harga yang ditentukan untuk sapi jantan Rp. 5.000.000,00 menjadi Rp. 5.900.000,00 dan sapi betina Rp. 4.400.000,00 menjadi Rp. 4.900.00,00. Kelompok tani Desa Peniti, Seberang Kapuas, dan Kumpang Bis harga yang ditentukan Rp. 3.700.000,00 menjadi Rp. $3.800 .000,00$.
Spesifikasi ternak yang dibeli juga menyimpang dari ketentuan yang ditetapkan yaitu sapi Bali berumur 1,5-2 tahun, tinggi gumba 102-105 cm dan postur tubuh ideal serta alat reproduksi normal. Ternak yang dibeli berumur 9-10 bulan, tinggi gumba $90-103 \mathrm{~cm}$. Beberapa ternak dengan postur tubuh yang tidak ideal banyak dijumpai setelah sekian lama dipelihara tidak bunting. Pelanggaran lainnya terjadi berupa pemungutan biaya transportasi ternak oleh tim pengadaan ternak sebesar Rp. 200.000,00/peternak. Penyimpangan pada pemanfaatan dana seharusnya tidak terjadi jika tim teknis kabupaten mendampingi serta memantau penggunaan dana tersebut.

Proses pengadaan bakalan. Proses pengadaan sapi bakalan di Kabupaten Sekadau untuk setiap desa dilakukan berbeda-beda, pengadaan sapi bakalan di Desa Engkresik dilakukan oleh tim pengadaan ternak serta melibatkan ketua kelompok yang didampingi ketua tim teknis kabupaten. Spesifikasi ternak yang dibeli berbeda dengan ketentuan yang seharusnya. Harga hanya diketahui oleh tim pengadaan ternak dan penjual sehingga penetuan harga tidak transparan. Pengadaan sapi bakalan di tani Desa Padak hanya melibatkan tim pengadaan ternak dan ketua tim teknis kabupaten. Sapi bakalan didatangkan dari Pontianak. Setelah sapi bakalan tiba di lokasi, ketua kelompok melakukan pembayaran sesuai dengan ketentuan yaitu Rp. 4.200.00,00/ekor untuk sapi betina dan Rp. 5.200.000,00/ekor untuk sapi jantan. Pengadaan sapi bakalan di Desa Peniti, Seberang Kapuas dan Kumpang Bis melibatkan ketua masing-masing kelompok tani dengan didampingi ketua tim teknis kabupaten, penyuluh lapangan, beserta tim pengadaan ternak. Sapi potong bakalan didatangkan dari Pulau Lombok. Penentuan harga tidak 
transparan karena pembayaran ternak dilakukan tim pengadaan ternak.

Proses pengadaan sapi bakalan dilakukan sudah cukup baik walaupun terjadi beberapa penyimpangan seperti ketidaksesuaian antar harga dan spesifikasi ternak yang telah ditentukan serta adanya biaya tambahan transportasi.

Perguliran bantuan (ternak). Dari hasil penelitian ditemukan terjadi beberapa penyimpangan yang dilakukan mengenai mekanisme perguliran ternak. Hal ini terjadi karena anggota kelompok masing-masing desa menganggap penggaduh pertama lebih sulit memelihara ternak karena sapi yang diterima masih dara. Sapi dara biasanya masih sulit untuk dikawinkan dan bisa bunting. Pertimbangan tersebut yang menjadi alasan kelompok membuat aturan perguliran ternak yang menyimpang. Penyimpangan lain juga terjadi pada pelimpahan ternak sebelum ternak tersebut beranak dan adanya perguliran ternak di luar kelompok tani. Terjadinya penyimpangan perguliran ternak di kelompok tani dapat diatasi dengan pendampingan dan bimbingan dari tim teknis kabupaten beserta penyuluh lapangan. Pembuatan ketentuan mekanisme perguliran ternak oleh tim teknis kabupaten harus menyesuaikan dengan kondisi peternak di lapangan.

Perguliran ternak kepada kelompok baru. Dana berupa ternak yang disalurkan kepada kelompok tani merupakan pungutan modal yang perlu dipupuk menjadi modal kelompok, selanjutnya perguliran ternak kepada kelompok baru dilakukan jika seluruh anggota kelompok tani telah mendapat bantuan berupa induk ternak. Penentuan kelompok baru ditentukan oleh tim teknis kabupaten. Proses perguliran ternak ke kelompok baru di Kabupaten Sekadau belum dilakukan karena anggota kelompok tani belum seluruhnya mendapat perguliran induk.

Pendampingan program. Pendampingan program di Kabupaten Sekadau awal berjalan dengan rutin setiap bulan, namun setelah program ini berjalan dua tahun penyuluh lapangan tidak pernah datang ke kelompok untuk melakukan pendampingan. Penyuluh lapangan hanya datang ketika mengambil laporan bulanan, sedangkan tim teknis kabupaten datang ke lokasi saat diminta ketua kelompok jika terjadi masalah mengenai program

Berdasarkan gambaran kegiatan pendampingan diatas secara umum pendampingan program pengembangan agribisnis peternakan sapi potong di Kabupaten Sekadau tidak efektif. Penyuluh lapangan dan tim teknis kabupaten jarang mengunjungi kelompok, dan tidak melakukan tugas-tugasnya dengan baik seperti memberikan sosialisasi terus menerus tentang kegiatan program, memfasilitasi pelatihan-pelatihan dan pertemuan kelompok serta memberikan bimbingan teknis yang diperlukan peternak. Tidak rutinnya penyuluh lapangan dan tim teknis kabupaten ke lokasi disebabkan karena jarak antar lokasi penerima bantuan cukup berjauhan dengan prasarana jalan kurang mendukung serta beberapa penyuluh lapangan tidak memiliki fasilitas kendaraan dan tidak tinggal di lokasi.

Monitoring pelaksanaan. Monitoring pelaksanaan pada program pengembangan agribisnis peternakan di Kabupaten sekadau dilakukan oleh tim teknis kabupaten dan tim pembina dari provinsi. Kegiatan tersebut dilakukan setiap enam bulan atau setiap tahun secara bertahap. Seharusnya kegiatan monitoring bisa membantu peternak menyelesaikan masalah yang dihadapi serta memantau perkembangan kelompok sasaran, namun pada pelaksanaannya tim pembina provinsi tidak pernah melakukan monitoring ke kelompok dan tim teknis kabupaten datang ke lokasi sebanyak dua sampai tiga kali untuk melakukan monitoring selama berlangsungnya program. Kondisi ini disebabkan karena kesibukan tim pembina provinsi dan jauhnya jarak dari propinsi ke lokasi dan kondisi jalan yang rusak juga menjadi faktor kendala.

\section{Harapan program}

Peningkatan populasi ternak. Program pengembangan sapi potong telah berhasil meningkatkan populasi di setiap desa. Peningkatan populasi sapi potong bantuan tersaji pada Tabel 6 .

Peningkatan populasi ternak tergolong rendah, hal ini terlihat dari selama waktu 4 tahun untuk kelompok tani Desa Peniti hanya bertambah 34 ekor atau 36,17\%, Desa Seberang Kapuas 29 ekor atau $32,58 \%$, dan Desa Kumpang Bis 40 ekor atau $40 \%$. Kondisi ini belum mencapai target yang ditentukan yaitu peningkatan populasi sebesar $100 \%$ pada tahun pertama. Sama seperti yang terjadi di kelompok tani Desa Engkresik hanya bertambah 22 ekor atau 26,19\% dan Desa Padak 27 ekor atau $31,03 \%$ dalam waktu dua tahun. Tabel 6 menunjukkan peningkatan populasi terbanyak terjadi di Desa Kumpang Bis, hal ini dimungkinkan karena rerata curahan waktu untuk mengelola usaha ternaknya lebih banyak dibandingkan dengan desa lainnya yaitu sebesar $0,116 \pm 0,163 \mathrm{HOK} / \mathrm{UT} /$ hari dan rerata jumlah tanggungan keluarga yang digunakan untuk mengelola usaha ternaknya lebih banyak yaitu $3,86 \pm 1,21$ orang.

Rendahnya peningkatan populasi sapi potong bantuan disebabkan karena penampilan reproduksi sapi potong bantuan rendah yang bisa dideteksi dengan service per conception (S/C) yang tinggi dan angka mortalitas yang juga tinggi. Faktor 
Tabel 6. Peningkatan populasi ternak sapi bantuan (ekor) dan peternak penerima bantuan (orang) (population increase of grant cattle (head) and number of granted farmers (person))

\begin{tabular}{|c|c|c|c|c|c|c|c|c|c|}
\hline \multirow{2}{*}{ No } & \multirow{2}{*}{$\begin{array}{l}\text { Desa } \\
\text { (village) }\end{array}$} & \multicolumn{2}{|c|}{$\begin{array}{c}\sum \text { awal (early } \\
\text { number) }\end{array}$} & \multicolumn{2}{|c|}{$\begin{array}{c}\sum \text { Saat penelitian } \\
\text { (on research number) }\end{array}$} & \multicolumn{4}{|c|}{$\sum$ Peningkatan (increasment) } \\
\hline & & $\begin{array}{c}\text { Sapi } \\
\text { (cattle) }\end{array}$ & $\begin{array}{l}\text { Peternak } \\
\text { (farmer) }\end{array}$ & $\begin{array}{c}\text { Sapi } \\
\text { (cattle) }\end{array}$ & $\begin{array}{l}\text { Peternak } \\
\text { (farmer) }\end{array}$ & $\begin{array}{c}\text { Sapi } \\
\text { (cattle) }\end{array}$ & $\begin{array}{c}\text { Persen } \\
\text { (percent) }\end{array}$ & $\begin{array}{l}\text { Peternak } \\
\text { (farmer) }\end{array}$ & $\begin{array}{c}\text { Persen } \\
\text { (percent) }\end{array}$ \\
\hline 1 & Engkresik & 62 & 28 & 84 & 33 & 22 & 14,47 & 5 & 8,62 \\
\hline 2 & K. Bis & 60 & 30 & 100 & 43 & 40 & 26,32 & 13 & 22,41 \\
\hline 3 & Peniti & 60 & 30 & 94 & 46 & 34 & 22,37 & 16 & 27,59 \\
\hline 4 & Padak & 60 & 28 & 87 & 37 & 27 & 17,76 & 9 & 15,52 \\
\hline 5 & S. Kapuas & 60 & 30 & 89 & 45 & 29 & 19,08 & 15 & 25,86 \\
\hline & Total & 302 & 146 & 454 & 204 & 152 & 100,00 & 58 & 100,00 \\
\hline
\end{tabular}

$\sum=$ Jumlah, K. Bis = Kumpang Bis, S. Kapuas = Seberang Kapuas.

lainnya yang mempengaruhi rendahnya peningkatan populasi sapi potong disebabkan karena pola pemeliharaan ternak belum intensif, rendahnya rerata pengalaman beternak peternak yang hanya $1,61 \pm 1,20$ tahun serta rerata alokasi waktu yang dicurahkan untuk mengelola usaha peternakannya sebesar 0,078 $\pm 0,082 \mathrm{HOK} / \mathrm{UT} / \mathrm{hari}$.

Rerata nilai S/C ternak dari masing-masing

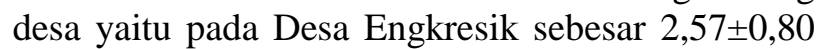
kali, Desa Kumpang Bis sebesar 3,91 $\pm 1,30$ kali, Desa Peniti sebesar 3,91 $\pm 0,96$ kali, Desa Padak sebesar 3,33 $\pm 0,83$ kali, Desa Seberang Kapuas

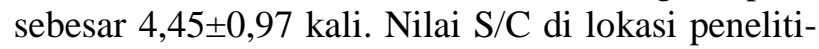
an lebih tinggi dibanding dengan pernyataan Bandini (2003), yang melaporkan bahwa S/C pada sapi Bali adalah 1,2-1,8 kali lebih baik dari pada sapi Madura (1,7-2,0 kali). Waktu mengawinkan yang tepat dan teknik inseminasi merupakan faktor yang mempengaruhi nilai $S / C$.

Angka mortalitas sapi potong di setiap desa adalah sebagai berikut di Desa Engkresik sebesar 13,11\%, Desa Kumpang Bis sebesar 20,23\%, Desa Peniti sebesar 15,91\%, Desa Padak adalah sebesar 14,81\%, Desa Seberang Kapuas adalah sebesar $22,93 \%$. Angka mortalitas sapi potong di Kabupaten Sekadau lebih tinggi dibandingkan dengan hasil penelitian Tanuri (1999) cit. Nazlah (2008) bahwa angka mortalitas sapi Bali sebesar 7,26\% $\pm 0,49 \%$. Tingginya angka mortalitas disebabkan karena tatalaksana pemeliharaan yang tidak baik dan masih ekstensif sehingga banyak ternak yang terserang penyakit kembung dan diare karena sebagaian besar peternak memelihara ternaknya di kebun kelapa sawit.

Kontribusi beternak sapi potong terhadap penerimaan keluarga. Rerata kontribusi penerimaan asal ternak sapi untuk setiap desa di Kabupaten Sekadau tersaji pada Tabel 7. Tabel 7 menunjukkan kontribusi penerimaan dari sapi potong yang tertinggi yaitu di Desa Kumpang Bis sebesar 24,09\%, selanjutnya Desa Peniti sebesar
23,45\%, Desa Seberang Kapuas Sebesar 13,03\%, Desa Engkresik sebesar 8,20\%, dan Desa Padak sebesar $9,46 \%$. Tingginya kontribusi penerimaan dari sapi potong di Desa Kumpang Bis disebabkan karena alokasi waktu yang dicurahkan untuk mengelola usaha ternaknya cukup tinggi rerata sebesar 0,116 $\pm 0,163 \mathrm{HOK} / \mathrm{UT} / \mathrm{hari}$.

Usaha untuk meningkatkan penerimaan dari sapi potong dapat dilakukan dengan cara memberikan penyuluhan atau pelatihan oleh penyuluh lapangan dan dinas terkait kepada peternak tentang manajemen pemeliharaan ternak yang baik dan mendorong peternak agar beternak secara intensif.

\section{Kesimpulan}

Pelaksanaan program pengembangan agribisnis peternakan sapi potong di Kabupaten Sekadau belum optimal. Hal ini dapat dilihat dari adanya beberapa aturan yang ditetapkan belum sesuai dengan pelaksanaan di lapangan seperti masih kurangnya sosialisasi yang dilakukan pada tingkat kelompok, hal ini diketahui karena masih adanya anggota kelompok yang belum mengerti tentang tujuan dan pelaksanaan program, pada penyeleksian calon penerima bantuan beberapa kriteria seleksi tidak dilaksanakan karena kurangnya pengawasan oleh tim teknis, pada pembentukan kelompok tani ada dua desa yang membentuk kelompok ketika adannya program, penyusunan rencana usaha kelompok dan penentuan bangsa serta spesifikasi ternak tidak melibatkan anggota kelompok. Spesifikasi ternak yang diterima penggaduh tidak sesuai dengan ketentuan sehingga menyebabkan peternak merasa dirugikan. Pada tahap implementasi terjadi penyalahgunaan pemanfaatan dana oleh kelompok tani. Terjadinya perbedaan mekanisme perguliran ternak bantuan di masingmasing desa yang disebabkan bentuk penyesuaian antara aturan yang ditetapkan dengan pelaksanaan pada kelompok. 
Tabel 7. Kontribusi penerimaan dari sapi potong (\%) terhadap penerimaan keluarga (income contribution from beef cattle on household income (\%))

\begin{tabular}{|c|c|c|c|c|}
\hline \multirow{2}{*}{$\begin{array}{c}\text { Desa } \\
\text { (village) }\end{array}$} & \multicolumn{3}{|c|}{ Penerimaan (Rp/tahun) (income (Rp/year)) } & \multirow{2}{*}{$\begin{array}{l}\text { Total }(\mathrm{Rp} / \mathrm{tahun}) \\
\text { (total (Rp/year)) }\end{array}$} \\
\hline & $\begin{array}{c}\text { Non peternakan (non } \\
\text { farming) }\end{array}$ & Sapi potong $(b$ & Ternak lain & \\
\hline Engkresik & $19.243 .428,00(91,60)$ & $1.723 .809,00 \quad(8,20)$ & $44.285,00(0,20)$ & $21.001 .523,00(100)$ \\
\hline K.Bis & $21.668 .181,00(74,80)$ & $6.943 .181,00(24,09)$ & $343.409,00(1,11)$ & $.772,00(100)$ \\
\hline Peniti & $17.623 .636,00(76,08)$ & $5.431 .818,00(23,45)$ & $107.363,00(0,47)$ & $23.162 .818,00(100)$ \\
\hline Padak & 43.657.142,00 (90,09) & $4.585 .714,00$ & $217.142,00(0,45)$ & $48.460 .000,00(100)$ \\
\hline S.Kapuas & $32.154 .000,00(86,61)$ & $4.840 .909,00(13,03)$ & $136.363,00(0,36)$ & 37.131.272,00 (100) \\
\hline
\end{tabular}

K. Bis : Kumpang Bis.

S. Kapuas : Seberang Kapuas.

Non peternakan: penerimaan berasal dari karet, kelapa sawit, warung dan gaji PNS (get income from ruber, palm oil, shop, and salary).

Sapi potong : penerimaan berasal dari beternak sapi (get income from cattle farm).

Ternak lain : penerimaan berasal dari ternak babi dan ayam buras (get income from swine and native chicken farms).

Angka dalam kurung menunjukkan persentase (inside the blanked is the percentage)

Program pengembangan agribisnis peternakan sapi potong yang dilaksanakan di Kabupaten Sekadau telah berhasil meningkatkan populasi sapi potong sebanyak 152 ekor, serta dapat memberikan kontribusi penerimaan dari sapi potong terhadap penerimaan keluarga peternak penerima bantuan sebesar $8,20 \%$ sampai dengan $24,09 \%$ pertahun.

\section{Daftar Pustaka}

Azis, A.M. 1993. Agroindustri Sapi Potong. Cetakan V. BPFE, Yogyakarta.

Badan Pusat Statistik Kabupaten Sekadau. 2008. Kabupaten Sekadau dalam Angka, Sekadau.

Bandini, Y. 2003. Sapi Bali. Penebar Swadaya, Jakarta.
Dinas Pertanian, Perikanan dan Peternakan Kabupaten Sekadau. 2008. Kabupaten Sekadau dalam Angka Tahun 2008, Sekadau.

Guntoro, B. and J. Udomsade. 2005. Type of participation of local community in sustainable tourism development in Ban Ruammit, Chiang Rai, Thailand. The Kasetsart Journal Social Sciences. 20: 249262.

Nazlah. 2008. Evaluasi pencapaian program pengembangan sapi potong pola gaduhan di Kabupaten Mamuju. Tesis. Fakultas Peternakan Program Pascasarjana Universitas Gadjah Mada, Yogyakarta.

Sugeng, Y.B. 2003. Sapi potong. Penebar Swadaya, Jakarta. 